\title{
Severe Guillain-Barré syndrome associated with chronic active hepatitis $C$ and mixed cryoglobulinemia: a case report
}

\author{
Alexandre Chlilek ${ }^{1}$, Claire Roger ${ }^{2}$, Laurent Muller ${ }^{2}$, Marie-Josée Carles ${ }^{1}$, Robin Stephan', Didier Laureillard ${ }^{3}$, \\ Jean-Philippe Lavigne ${ }^{1,4^{*}}$ (D) Jean-Yves Lefrant ${ }^{2}$ and Albert Sotto ${ }^{3,4}$
}

\begin{abstract}
Background: We describe a case of severe Guillain-Barre syndrome (GBS) associated with chronic active hepatitis C and mixed cryoglobulinemia (MC). To our knowledge, this association between GBS and hepatitis C virus (HCV) infection has been rarely reported.

Case presentation: A 56-year-old man developed symmetrical muscle weakness in all extremities, areflexia and sensorial disorder followed by acute respiratory failure associated with chronic active hepatitis $C$, which was confirmed by the presence of anti-HCV antibodies in the serum and persistence of HCV RNA viral load for more than 6 months. Chronic hepatitis C was further complicated by type 3 MC. Electromyography showed peripheral nerve injury (mainly in axon). A severe acute motor sensory axonal neuropathy (AMSAN) was diagnosed. After treatment with intravenous immunoglobulin and plasma exchange followed by antiviral therapy by direct-acting antiviral agent, patient showed progressive recovery and was transferred 3 months after his first admission to a rehabilitation center.

Conclusions: Our case reported a severe GBS associated with HCV infection and MC. EMG classified for the first time the subtype of GBS (severe AMSAN) correlated with severe clinical form. HCV infection should be screened in high-risk patients to prevent silent progression of the chronic hepatitis $C$ and its potentially severe extra-hepatic manifestations.
\end{abstract}

Keywords: Chronic hepatitis C, Hepatitis C virus, Guillain-Barre syndrome, Mixed cryoglobulinemia, Extra-hepatic manifestations

\section{Background}

Hepatitis $\mathrm{C}$ virus (HCV) infection, the second most common chronic viral infection in the world, is an important public-health concern and leads to substantial mortality [1]. HCV causes asymptomatic acute hepatitis in 80 to $90 \%$ of cases and chronic hepatitis in 55 to $85 \%$ of infected individuals in the absence of treatment [2]. Patients with chronic active hepatitis $\mathrm{C}$ are known to be at risk of developing liver complications, i.e., cirrhosis and liver cancer but they are also susceptible to present numerous extra-hepatic manifestations (EHMs)

\footnotetext{
* Correspondence: jean.philippe.lavigne@chu-nimes.fr

'Service de Microbiologie, CHU Carémeau, 30029 Nîmes, France

${ }^{4}$ Université de Montpellier, 186 Chemin du Carreau de Lanes, 30908, cedex

02 Nîmes, France

Full list of author information is available at the end of the article
}

which are often underestimated [3]. Mixed cryoglobulinemia (MC) syndrome, a systemic autoimmune vasculitis, is the most prevalent EHM but others have been recently reported including many neurological manifestations [3-6].

Guillain-Barre syndrome (GBS) is the most frequent and severe acute paralytic neuropathy worldwide [7]. Acute respiratory failure can complicate GBS in $20-30 \%$ of cases and requires admission in intensive care unit (ICU) [7]. The mechanism of GBS is based on demyelinating lesions of peripheric nerves which often occur after infectious episode by autoimmune cross reaction [8]. Over the past decades, the cases of GBS caused by Campylobacter jejuni and numerous viral agents have greatly increased [7]. Recently, the emerging relation between GBS and Zika virus infection has aroused general

(c) The Author(s). 2019 Open Access This article is distributed under the terms of the Creative Commons Attribution 4.0 International License (http://creativecommons.org/licenses/by/4.0/), which permits unrestricted use, distribution, and reproduction in any medium, provided you give appropriate credit to the original author(s) and the source, provide a link to the Creative Commons license, and indicate if changes were made. The Creative Commons Public Domain Dedication waiver (http://creativecommons.org/publicdomain/zero/1.0/) applies to the data made available in this article, unless otherwise stated. 
interest as the global epidemic spreads [9]. To our best knowledge, only seven cases of GBS associated with $\mathrm{HCV}$ infection have been reported so far [10-13]. Here, we report one case of severe GBS associated with chronic active hepatitis $\mathrm{C}$ and $\mathrm{MC}$.

\section{Case presentation}

A 56 year-old male patient was admitted to our hospital emergency for muscle weakness of all limbs and areflexia (Fig. 1). His past medical history was marked by intravenous drug addiction (started at the age of 28 and currently treated by buprenorphine) and chronic respiratory failure after chronic obstructive pulmonary disease (tobacco consumption estimated at 36 pack-years). A serum test performed 1 year ago showed positive anti-HCV antibodies on ELISA (Enzyme Linked ImmunoSorbent Assay) confirmed by LIA (Line ImmunoAssay) with HCV RNA viral load at $87 \mathrm{IU} / \mathrm{mL}$. At the same time, liver function tests indicated elevated levels of alanine aminotransferase (ALT) to $256 \mathrm{IU} / \mathrm{L}(10-50 \mathrm{IU} / \mathrm{L})$ and aspartate aminotransferase (AST) to $123 \mathrm{IU} / \mathrm{L}(10-50 \mathrm{IU} / \mathrm{L})$. Chronic $\mathrm{HCV}$ infection was proven by persistence of viral load with a $3 \log$ increase $(25200 \mathrm{U} / \mathrm{mL})$ on a blood test withdrawn 4 months ago.

On admission, neurological physiological examination revealed consciousness, quadriplegia of all the limbs with emphasis in arms and right side, sensorial disorders in legs, decreased muscle tension and tendon areflexia in all the limbs, without aphasia, facial nerve palsy or diplopia.
Four days after emergency admission, the patient was transferred to our ICU for acute respiratory failure. Physical examination showed dyspnea, tachypnea and sharp pulling necessitating rapid sequence intubation and mechanical invasive ventilation associated with loss of consciousness (Glasgow Coma Score of 10). There was no jaundice or abdominal pain. Blood gas demonstrated severe hypoxemia $\left(\mathrm{pO}_{2} 43.8 \mathrm{mmHg}\right)$ and hypercapnia associated with respiratory acidosis $\left(\mathrm{pCO}_{2} 99.1 \mathrm{mmHg}, \mathrm{pH}\right.$ $7.06, \mathrm{HCO}_{3}{ }^{-} 28.2 \mathrm{mmol} / \mathrm{L}$ ). Blood tests showed lactates $3.0 \mathrm{mmol} / \mathrm{L}$, white blood cells $31 \times 10^{9} / \mathrm{L}$, Hemoglobin $12.6 \mathrm{~g} / \mathrm{dL}, \mathrm{C}$-reactive protein $14.9 \mathrm{mg} / \mathrm{L}$. The liver assessment was normal. Cardiac ultrasound exam ruled out any cardiac origin of acute respiratory failure. Chest $\mathrm{X}$ ray did not show any sign of pneumonia but Haemophilus influenzae was identified in pulmonary samples. Cerebrospinal fluid (CSF) examination showed an absence of leukocyte, $5.5 \mathrm{mmol} / \mathrm{L}$ glucose level, and $33 \mathrm{mg} / \mathrm{dL}$ protein level, which didn't suggest albuminocytologic dissociation. Cerebral and medullary magnetic resonance imaging indicated no abnormalities.

Based on initial neurological examination performed in the Department of emergency and respiratory involvement in the ICU, the physicians suspected that the patient presented with GBS. On day 2 after admission in ICU, treatment with intravenous immunoglobulins at a dose of $0.4 \mathrm{~g} / \mathrm{kg}$ per day for 5 days was initiated. Afterwards, five plasma exchange sessions were implemented over 2 weeks.

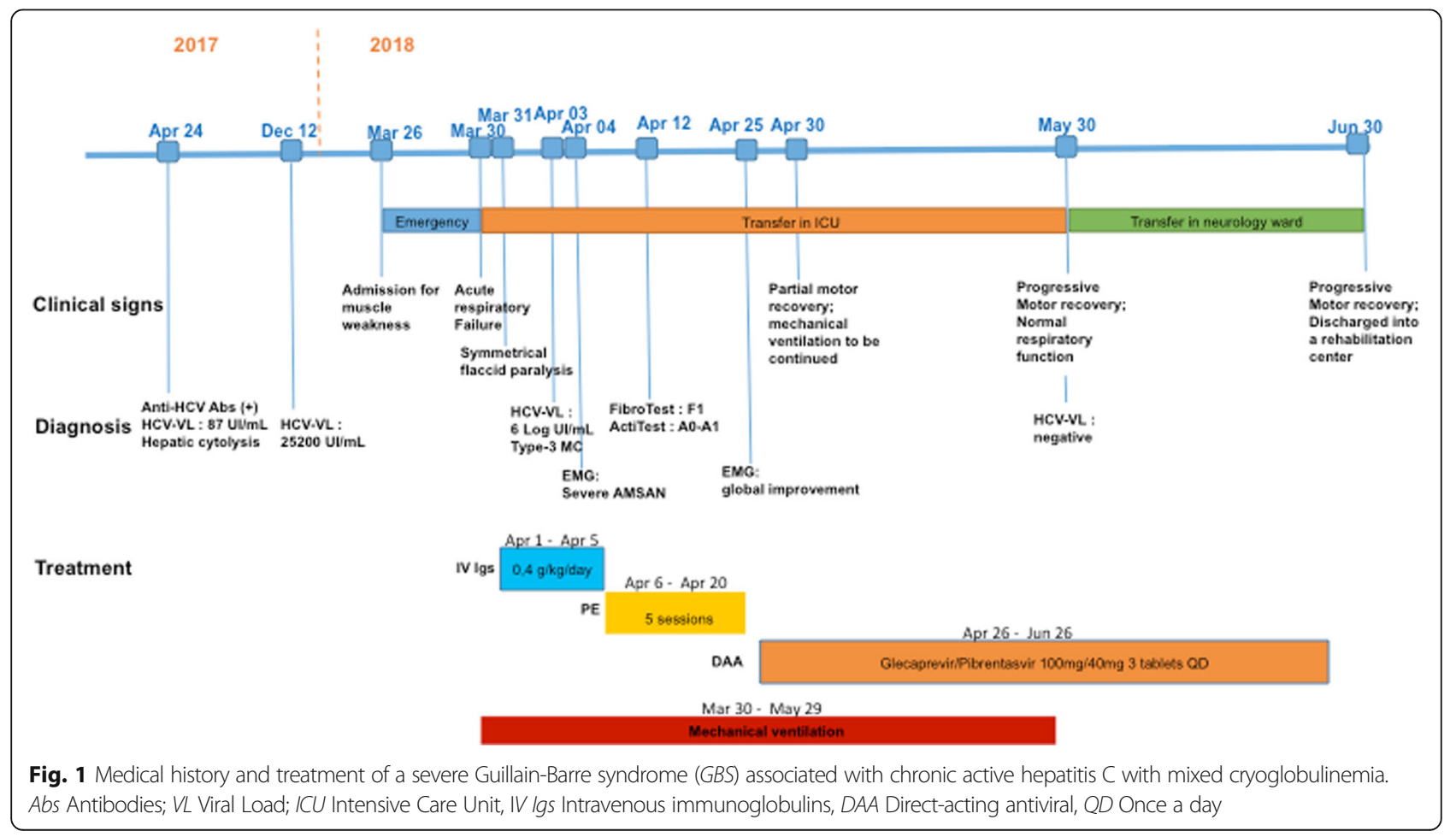


On day 4 after admission in the ICU, serological study for anti-HCV antibodies was positive and HCV RNA blood viral load was raised to $1710000 \mathrm{IU} / \mathrm{mL}$ with $\mathrm{HCV}$ assignment into genotype 4. Liver function tests indicated new increased levels of ALT to $103 \mathrm{IU} / \mathrm{L}$ (10-50 IU/L) and AST to $86 \mathrm{IU} / \mathrm{L}$ (10-50 IU/L). No serological evidence was found for Campylobacter jejuni infection, human immunodeficiency virus, hepatitis $B$ virus and syphilis. Hepatitis A virus and cytomegalovirus serology indicated positive IgG. Serum electrophoresis showed marked polyclonal hypergammaglobulinemia with elevated gammaglobulin level to $20.9 \mathrm{~g} / \mathrm{L}$ $(8.0-13.5 \mathrm{~g} / \mathrm{L})$ including $17.5 \mathrm{~g} / \mathrm{L}$ IgG $(6.7-12.4 \mathrm{~g} / \mathrm{L})$ and 2.0 $\mathrm{g} / \mathrm{L} \operatorname{IgM}(0.6-1.6 \mathrm{~g} / \mathrm{L})$. The screening for cryoglobulin by serum cryoprecipitation was positive and immunoelectrophoresis indicated the presence of polyclonal IgG combined with polyclonal IgM. These assays were confirmed twice ten days apart, attesting type-3 MC. In addition, one other immunological test reported decreased serum complement level to $39 \mathrm{U} / \mathrm{mL}(42-95 \mathrm{U} / \mathrm{mL})$ with reduction in $\mathrm{C} 4 \mathrm{com}$ plement fraction to $0.14 \mathrm{~g} / \mathrm{L}(0.18-0.42 \mathrm{~g} / \mathrm{L})$.

Electromyography (EMG) carried out at day 5 after admission in ICU showed prolonged distal motor latency, major decrease of motor and sensory nerve action potentials amplitude, absence of voluntary activity and several spontaneous electromyographic activity in all the territories studied, demonstrating evidence of severe acute motor sensory axonal neuropathy (AMSAN) with demyelinating lesions compatible with a peculiar type of GBS.

FibroTest and ActiTest performed on day 14 after admission in ICU showed minimal fibrosis stage (F1) and minimal activity grade (A0-A1), respectively. After plasma exchange sessions, the patient was treated for 2 months with direct-acting antiviral agent (DAA) (glecaprevir/pibrentasvir).

During the first month, the patient showed very slow motor recovery and difficulties with weaning from mechanical ventilation requiring performing tracheostomy. Control EMG performed on day 27 indicated marked improvements in distal motor latencies and motor and sensory nerve action potentials amplitude, major decrease of spontaneous electromyographic activities and recovery of voluntary activity in all the territories studies, suggestive of GBS being recovered.

Afterwards, the patient improved with progressive recovery of muscle strength and normal respiratory function. After one month of DAA therapy, HCV ARN was undetectable and liver enzymes were normal. There was no relapse. The patient was transferred 3 months after his first admission to a rehabilitation centre.

\section{Discussion and conclusion}

GBS is an acute immune-mediated polyradiculoneuropathy that results in rapidly progressing symmetric motor paralysis and decreased tendon reflexes or areflexia, often with sensory deficits and cranial nerve involvement. The acute progression of limb weakness, 1-2 weeks after immune stimulation often triggered by an infectious disease, proceeds to its peak clinical deficit in 2-4 weeks [14]. Examination of the CSF classically shows cytoalbuminological dissociation, i.e., the combination of a normal cell count and increased protein level. GBS is also a clinically diverse disorder with several distinctive variants and atypical cases. Nerve conduction studies can help clinicians to make the diagnosis and to consider prognosis enabling them to divide GBS into acute inflammatory demyelinating polyneuropathy, acute motor axonal neuropathy, or AMSAN [15]. To treat GBS, IVIgs or plasma exchange have proved to be effective and should be started as soon as possible especially in patients with rapidly progressive weakness before irreversible nerve damage taken place [16]. In our case, GBS was suspected once the patient was found as having acute respiratory failure after symmetrical paralysis of all limbs,. We didn't get the proof from CSF because of the absence of albuminocytologic dissociation. In fact, normal protein level is reported in approximately $50 \%$ of cases when determined in the first 4 days after the onset of the disease [14] which does not make the diagnosis unlikely or even exclude GBS. EMG confirmed the diagnosis and demonstrated AMSAN. This electrophysiological GBS subtype is very scarce in Europe and North America [17]. It is generally correlated to more severe limb weakness, poorer outcome than the others subtypes and the patients often require mechanical ventilation [18]. However, most of AMSAN patients have past history of diarrhea or serological evidence of $C$. jejuni infection [18], which was not highlighted here.

The patient had chronic active hepatitis C. In developed countries, HCV infections are mainly caused in high risk populations, especially persons who inject drugs [19]. In the absence of previous HCV serology, it is not excluded that the patient had already chronic $\mathrm{HCV}$ infection on the blood test withdrawn one year before admission in our ICU, suggestive of subclinical transition from a clinically silent acute $\mathrm{HCV}$ infection. HCV RNA viral load was positive on the first blood test and persistent more than 6 months before the onset of neurological symptoms. Meanwhile, liver enzymes were initially positive on the first blood test then negative on the liver function test withdrawn at emergency admission with a new increase 4 days after in the ICU. This biological profile is compatible with chronic hepatitis $C$ where transaminases are known to fluctuate rapidly. Moreover, cases of asymptomatic rise of transaminases contemporaneous of the acute phase of GBS have already been described [10, 12]. Thus, we could hypothesize that chronic hepatitis $\mathrm{C}$ may have been the trigger of GBS. 
Moreover, the patient presented type- $3 \mathrm{MC}$. MC is based on the presence of mixed cryoglobulins in the circulation consisting either of a monoclonal Ig, plus a polyclonal (type II cryoglobulins), or two polyclonal Igs (type III). Serum cryoglobulins are frequently detected in HCV-infected patients, especially in Southern Europe (50-70\%) [20]. MC syndrome is generally classified as a systemic small-vessel vasculitis that affects up to 10$15 \%$ of subjects chronically infected with HCV [20] and may involve kidneys, joints, skin and peripheral nerves. Peripheral neuropathy, the most common neurologic complication of $\mathrm{HCV}$ [4], is more prominent with $\mathrm{HCV}$ associated MC where the most frequently described form is a symmetrical sensory-motor polyneuropathy with predominant sensory features [21]. However, the presence of MC doesn't increase overall risk of developing a neuropathy [22] and the pathophysiology of neuropathy associated with $\mathrm{HCV}$ is not definitively known [21]. Furthermore, the patient recovered without the use of rituximab. Immunosuppressive agents as rituximab constitute the best non-antiviral therapeutic option for refractory or severe forms of $\mathrm{MC}$ associated with chronic HCV infection [23]. However, although the clinical experience on the use of the new DAAs currently remains very limited, recent evidence-based recommendations advise the use of these new antiviral treatments for all patients presenting $\mathrm{HCV}$-related $\mathrm{MC}$ with no clear indications on how to combine them and nonantiviral treatment [24].

As far as we know, only seven cases of GBS associated with hepatitis C have been reported. In 1993, De Klippel et al. reported the first case in Belgium [10]. A woman manifested distal paresis of both legs and arms with areflexia and paresthesia. Anti-HCV antibodies were detectable in the serum. Nerve conduction studies met the criteria of GBS and were consistent with a demyelinating neuropathy. Blood test results, rapid normalization of liver enzymes and complete absence of fibrosis on liver biopsy suggested to clinicians GBS associated with resolving acute HCV infection. In 1995, a second case of $\mathrm{HCV}$ infection associated with GBS was described in France in a patient presenting chronic active hepatitis $\mathrm{C}$ [11]. In 1998, Lacaille et al. reported two others cases [12]. The third case was a 51-year-old man who presented rapidly progressive paresis of four limbs, areflexia and paresthesia further complicated by paralysis of respiratory muscles involving mechanical ventilation. Cerebrospinal fluid was normal and nerve conduction studies showed an asymmetrical axono-myelinic polyradiculoneuritis suggestive of GBS. Anti-HCV antibodies were positive and liver biopsy indicated chronic active hepatitis. The fourth case was a young woman who developed paresis and sensory loss of all her four limbs with areflexia two years after the end of $\alpha$-interferon treatment for chronic hepatitis $\mathrm{C}$ with moderate activity. CSF examination showed slightly elevation of proteins and normal cell count. EMG showed partial peripheral neurogenic symptoms, with normal conduction speed. After IVIg therapy, the patient gradually recovered but experienced a relapse. Finally, she fully improved after four courses of plasma exchange. In 2001, Massengo et al. reported the fifth case presenting GBS caused by hepatitis $C$ associated with cryoglobulinemia [13]. In 2008 and 2010, two others cases with respectively atypical and typical features for GBS associated with pegylated interferon alpha-2a have been published $[25,26]$. It was worth to mention that GBS has also been reported in association with non-A, non-B hepatitis [27-29]; perhaps these cases were due to $\mathrm{HCV}$ infection.

There were some limitations in our case. Firstly, we didn't get another CSF sample to prove albuminocytologic dissociation. However, according to the recently proposed new diagnostic classification, GBS could be diagnosed by clinical characteristics and electrophysiological examinations, without the need of CSF examinations, and whether or not they disclose existing diagnostic criteria [30]. On the other hand, we had not previous serum tests to explore history of $\mathrm{HCV}$ infection specially to date the transition from acute to chronic infection.

In conclusion, we describe a case of GBS associated with chronic active hepatitis $C$ and MC. GBS should be added to the list of EHMs of hepatitis $\mathrm{C}$ as well as HCV as an additional cause of GBS. Moreover, we classified the subtype of GBS (severe AMSAN) based on the electrophysiology characteristics and correlated to the clinical presentation. We thus observed that chronic active hepatitis $\mathrm{C}$ is a general disorder which can lead to severe peripheral neuropathy requiring admission in ICU in absence of treatment. Hence the need, in the future, of setting up effective programs to make HCV screening and treatment easier in high-risk populations who have chronic hepatitis C.

\section{Abbreviations \\ ALT: Alanine aminotransferase; AMSAN: Acute motor sensory axonal neuropathy; AST: Aspartate aminotransferase; CSF: Cerebrospinal fluid; DAA: Direct-acting antiviral agent; EHM: Extra-hepatic manifestation; ELISA: Enzyme linked immunosorbent assay; EMG: Electromyography; GBS: Guillain-Barre syndrome; HCV: Hepatitis C virus; LIA: Line immunoassay; MC: Mixed cryoglobulinemia}

\section{Acknowledgements}

We thank Sarah Kabani for her assistance.

\section{Authors' contributions}

$A C, C R, L M, D L, J Y L, J P L$, and $A S$ analyzed and interpreted the patient data. $A C, J P L$, and $A S$ drafted and wrote the manuscript. AC performed the literature search. MCJ and RS performed the virological analysis. CR, LM and $J Y L$ were in charge of the patient in the intensive care unit. CR, LM, MJC, RS, $\mathrm{DL}$, and JYL contributed to the assessment and discussion of the results. All authors read and approved the final manuscript. 


\section{Funding}

Not applicable.

\section{Availability of data and materials}

The datasets analysed during the current case report are available from the corresponding author on reasonable request.

\section{Ethics approval and consent to participate}

Not applicable.

\section{Consent for publication}

A written informed consent was obtained from the patient for publication of this case report. A copy of the written consent is available for review by the editors of this journal.

\section{Competing interests}

The authors declare that they have no competing interests.

\section{Author details}

'Service de Microbiologie, CHU Carémeau, 30029 Nîmes, France. ${ }^{2}$ Service de Réanimation Chirurgicale, CHU Carémeau, 30029 Nîmes, France. ${ }^{3}$ Service de Maladies Infectieuses et Tropicales, CHU Carémeau, 30029 Nîmes, France. ${ }^{4}$ Université de Montpellier, 186 Chemin du Carreau de Lanes, 30908, cedex 02 Nîmes, France.

Received: 1 November 2018 Accepted: 11 July 2019

Published online: 17 July 2019

\section{References}

1. Lanini S, Easterbrook PJ, Zumla A, Ippolito G. Hepatitis C: global epidemiology and strategies for control. Clin Microbiol Infect. 2016;22(10): 833-8.

2. Westbrook RH, Dusheiko G. Natural history of hepatitis C. J Hepatol. 2014; 61(Suppl 1):S58-68.

3. Cacoub P, Gragnani L, Comarmond C, Zignego AL. Extrahepatic manifestations of chronic hepatitis C virus infection. Dig Liver Dis. 2014; 46(Suppl 5):S165-73.

4. Mathew S, Faheem M, Ibrahim SM, Iqbal W, Rauff B, Fatima K, et al. Hepatitis C virus and neurological damage. World J Hepatol. 2016;8(12):545-56.

5. Adinolfi LE, Nevola R, Lus G, Restivo L, Guerrera B, Romano C, et al. Chronic hepatitis $C$ virus infection and neurological and psychiatric disorders: an overview. World J Gastroenterol. 2015:21(8):2269-80.

6. Iriana S, Curry MP, Afdhal NH. Neurologic manifestations of hepatitis C virus infection. Clin Liver Dis. 2017:21(3):535-42.

7. Willison HJ, Jacobs BC, van Doorn PA. Guillain-Barré syndrome. Lancet. 2016; 388(10045):717-27.

8. van den Berg B, Walgaard C, Drenthen J, Fokke C, Jacobs BC, van Doorn PA. Guillain-Barré syndrome: pathogenesis, diagnosis, treatment and prognosis. Nat Rev Neurol. 2014;10(8):469-82.

9. Cao-Lormeau VM, Blake A, Mons S, Lastere S, Roche C, Vanhomwegen J, Dub T, Baudouin L, Teissier A, Larre P, et al. Guillain-Barré syndrome outbreak associated with Zika virus infection in French Polynesia: a casecontrol study. Lancet. 2016;387(10027):1531-9.

10. De Klippel N, Hautekeete ML, De Keyser J, Ebinger G. Guillain-Barré syndrome as the presenting manifestation of hepatitis $C$ infection. Neurology. 1993:43(10):2143.

11. Zylberberg $H$, Hagège $H$, Roualdes B, Meyrignac $C$, Chousterman M. Guillain-Barré syndrome in a patient with chronic active hepatitis $C$. Gastroenterol Clin Biol. 1995:19(5):551.

12. Lacaille $F$, Zylberberg $H$, Hagège $H$, Roualdès $B$, Meyrignac C, Chousterman M, et al. Hepatitis C associated with Guillain-Barré syndrome. Liver. 1998 18(1):49-51.

13. Massengo SA, Furby A, Stanescu C, Charasse C, Madigand M. Hepatitis C with cryoglobulinemia associated with Guillain-Barre syndromePresse Med 2001;30(15):739.

14. Fokke C, van den Berg B, Drenthen J, Walgaard C, van Doorn PA, Jacobs BC Diagnosis of Guillain-Barré syndrome and validation of Brighton criteria. Brain. 2014;137(Pt 1):33-43.

15. Ho TW, Mishu B, Li CY, Gao CY, Cornblath DR, Griffin JW, et al. Guillain-Barré syndrome in northern China. Relationship to campylobacter jejuni infection and anti-glycolipid antibodies. Brain. 1995;118 ( Pt 3):597-605.
16. Shahrizaila N, Yuki N. The role of immunotherapy in Guillain-Barré syndrome: understanding the mechanism of action. Expert Opin Pharmacother. 2011;12(10):1551-60.

17. Hadden RD, Cornblath DR, Hughes RA, Zielasek J, Hartung HP, Toyka KV, et al. Electrophysiological classification of Guillain-Barré syndrome: clinical associations and outcome. Plasma exchange/Sandoglobulin Guillain-Barré syndrome trial group. Ann Neurol. 1998;44(5):780-8.

18. Uncini A, Kuwabara S. Electrodiagnostic criteria for Guillain-Barrè syndrome: a critical revision and the need for an update. Clin Neurophysiol. 2012; 123(8):1487-95.

19. Shire NJ, Sherman KE. Epidemiology of hepatitis C virus. A Battle on New Frontiers. Gastroenterol Clin North Am. 2015:44(4):699-716.

20. Ferri C, Ramos-Casals M, Zignego AL, Arcaini L, Roccatello D, Antonelli A, et al. International diagnostic guidelines for patients with HCV-related extrahepatic manifestations. A multidisciplinary expert statement. Autoimmun Rev. 2016;15(12):1145-60.

21. Benstead TJ, Chalk CH, Parks NE. Treatment for cryoglobulinemic and noncryoglobulinemic peripheral neuropathy associated with hepatitis C virus infection. Cochrane Database Syst Rev. 2014;(12):CD010404.

22. Santoro L, Manganelli F, Briani C, Giannini F, Benedetti L, Vitelli E, et al. Prevalence and characteristics of peripheral neuropathy in hepatitis $C$ virus population. J Neurol Neurosurg Psychiatry. 2006;77(5):626-9.

23. Pietrogrande M, De Vita S, Zignego AL, Pioltelli P, Sansonno D, Sollima S, et al. Recommendations for the management of mixed cryoglobulinemia syndrome in hepatitis C virus-infected patients. Autoimmun Rev. 2011;10(8): 444-54

24. Ramos-Casals M, Al Z, Ferri C, Brito-Zerón P, Retamozo S, Casato M, et al. Evidence-based recommendations on the management of extrahepatic manifestations of chronic hepatitis C virus infection. J Hepatol. 2017;66(6): 1282-99.

25. Khiani V, Kelly T, Shibli A, Jensen D, Mohanty SR. Acute inflammatory demyelinating polyneuropathy associated with pegylated interferon alpha $2 a$ therapy for chronic hepatitis C virus infection. World J Gastroenterol. 2008;14(2):318-21.

26. Niazi MA, Azhar A, Tufail K, Feyssa EL, Penny SF, McGregory M, et al. Guillain-Barre syndrome associated with peginterferon alfa-2a for chronic hepatitis C: a case report. World J Hepatol. 2010;2(4):162-6.

27. Macleod WN. Sporadic non-a, non-B hepatitis and Epstein-Barr hepatitis associated with the Guillain-Barré syndrome. Arch Neurol. 1987;44(4):438-42.

28. Tabor E. Guillain-Barré syndrome and other neurologic syndromes in hepatitis A, B, and non-A, non-B. J Med Virol. 1987;21(3):207-16.

29. Gutzler F, Andrassy K, Kommerell B, Krieger D. Guillain-Barré polyneuropathy in Wegener's granulomatosis with pulmonary-renal syndrome. Dtsch Med Wochenschr. 1990:115(10):372-7.

30. Wakerley BR, Uncini A, Yuki N. GBS classification group, GBS classification group. Guillain-Barré and miller fisher syndromes--new diagnostic classification. Nat Rev Neurol. 2014;10(9):537-44.

\section{Publisher's Note}

Springer Nature remains neutral with regard to jurisdictional claims in published maps and institutional affiliations.

Ready to submit your research? Choose BMC and benefit from:

- fast, convenient online submission

- thorough peer review by experienced researchers in your field

- rapid publication on acceptance

- support for research data, including large and complex data types

- gold Open Access which fosters wider collaboration and increased citations

- maximum visibility for your research: over $100 \mathrm{M}$ website views per year

At BMC, research is always in progress.

Learn more biomedcentral.com/submissions 